\title{
Upper Cretaceous geosites on Golija Mountain - objects of geoheritage
}

\author{
Ljiljana Grujičić-Tešić ${ }^{1}$, Dragoman Rabrenović ${ }^{1}$, Jovan Kovačević ${ }^{2}$, Nataša Gerzina ${ }^{1}$ \\ and Nevenka Đerić ${ }^{1}$
}

${ }^{1}$ University of Belgrade, Faculty of Mining and Geology, Đušina 7, 11000 Belgrade, Serbia; (natasa.gerzina@rgf.bg.ac.rs)
${ }^{2}$ Geological Survey of Serbia, Rovinjska 12, 11000 Belgrade, Serbia

doi: $10.4154 / g c .2016 .28$

\section{Article history:}

Manuscript received March 25, 2016 Revised manuscript accepted August 16, 2016 Available online October 25, 2016

Keywords: geoheritage, geosite, geoconservation geotourism, rudists, Upper Cretaceous, Mt. Golija, SW Serbia

\begin{abstract}
The Upper Cretaceous rudist limestones are well-known from several localities in Serbia. Three of these localities (Svilanovo, Bele Vode and Kulizino Selo) are located in SW Serbia, on Golija Mt. These localities are crucial for understanding the development of the Upper Cretaceous shallow-water environments, thus this is an area of great scientific and educational value, particularly considering palaeontology, stratigraphy, palaeoecology and palaeogeography. One of the aims of this paper is to evaluate these geosites and their geotouristic potential, using Geosite Assessment Model (GAM), which is important for their geoconservation as well as for the sustainable development of the area.
\end{abstract}

\section{INTRODUCTION}

The systematic study of the geological heritage and geodiversity in Serbia started relatively recently (MARAN, 2008, 2010; RUNDIĆ \& KNEŽEVIĆ, 2005; MIJOVIĆ et al., 2005; KARAMATA \& MIJOVIĆ 2005; STOJANOVIĆ \& MIJOVIĆ, 2008; VUJIČIĆ et al., 2011; JOVANOVIĆ et al., 2012; RABRENOVIĆ et al., 2014; MARAN STEVANOVIĆ, 2015). An inventory of Serbian geoheritage sites includes approximately 650 geological, palaeontological, geomorphological, spelaeological and neotectonic sites (ĐUROVIĆ \& MIJOVIĆ, 2006).

This study focuses on the Upper Cretaceous limestone with rudist fauna in the area between Sjenica and Raška (Fig. 1). Here, there are several outcrops of major importance for scientific knowledge and study of Upper Cretaceous fossiliferous sediments. However, considering their geological and palaeontological characteristics, only three of these localities (Svilanovo, Kulizino Selo and Bele Vode) seem to be interesting from the aspect of geological heritage. These localities are very important from the geological point of view, thus the aim of this paper is to present the main scientific arguments for considering these localities to be a part of Serbian geoheritage.

Remains of rudist limestones are scattered on the slopes of Mt. Golija which is the highest mountain in SW Serbia. Mt. Golija has been under state protection as the Golija Nature Park, since 2001. The Golija Nature Park was placed in category I as a natural resource of exceptional importance. Because of the exceptionally well-preserved natural environment, but also because of its cultural resources, the committee of the UNESCO's Man and the Biosphere Programme (MAB) set up the Golija-Studenica Biosphere Reserve within the Golija Nature Park. Besides their scientific significance, the beautiful landscape and cultural heritage reveal the high touristic potential of these localities, thus making them quite important from educational, touristic and cultural points of view. All the three localities are easily accessible, since they are situated along asphalt roads.
The main purpose of this paper is to evaluate different geosites using the preliminary Geosite Assessment Model (GAM) proposed by VUJIČIĆ et al. (2011) in order to determine whether this area has the potential for geotourism development.

\section{GEOLOGICAL SETTING AND GEOSITES SELECTION}

The region of western and southwestern Serbia is characterized by an extremely complex geological setting, as a result of collisional processes between the Adria microplate and the European plate. The area is composed of the continental Drina-Ivanjica, Jadar-Kopaonik and East-Bosnian-Durmitor Units, as well as two ophiolite belts, which are remnants of oceanic crust that are derived from the Neotethys (DIMITRIJEVIĆ \& DIMITRIJEVIĆ, 1973; ROBERTSON \& KARAMATA, 1994; DIMITRIJEVIĆ, 2001; KARAMATA, 2006). Recent investigations showed that the double belt appearance (Western Vardar Zone and Dinaridic Ophiolite Belt) and complicated present day geological relationships between the continental and oceanic units are the results of Late Jurassic obduction, followed by strong folding and out of sequence thrusting (PAMIĆ et al., 1998; HRVATOVIĆ \& PAMIĆ, 2005; CSONTOS et al., 2003; SCHMID et al., 2008).

The Late Jurassic to Early Cretaceous transgressive phase, characterized predominantly by alluvial to neritic sedimentation, started after obduction and subsequent erosion in the DinaridicHellenic belt (PAMIĆ et al., 1998; PAMIĆ \& HRVATOVIĆ, 2000; SCHMID et al., 2008). In western and southwestern Serbia, however, these sediments are absent, possibly due to Early to mid-Cretaceous collisional processes (SCHMID et al., 2008). In this region, both Palaeozoic and Mesozoic sediments of the Drina-Ivanjica and Jadar-Kopaonik Units, which derived from the passive margin of Adria, and Jurassic rocks of oceanic origin that belong to the Vardar Zone, are unconformably overlain by Upper Cretaceous transgressive clastic sediments containing redeposited ophiolite fragments. Carbonate and terrigenous-carbonate sedimentation followed through the Upper Cretaceous until 


\section{Legend:}

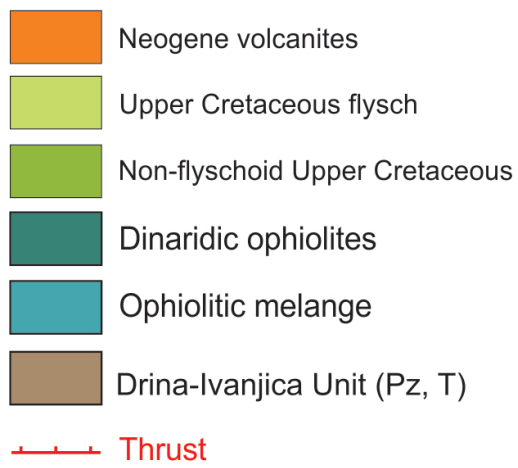

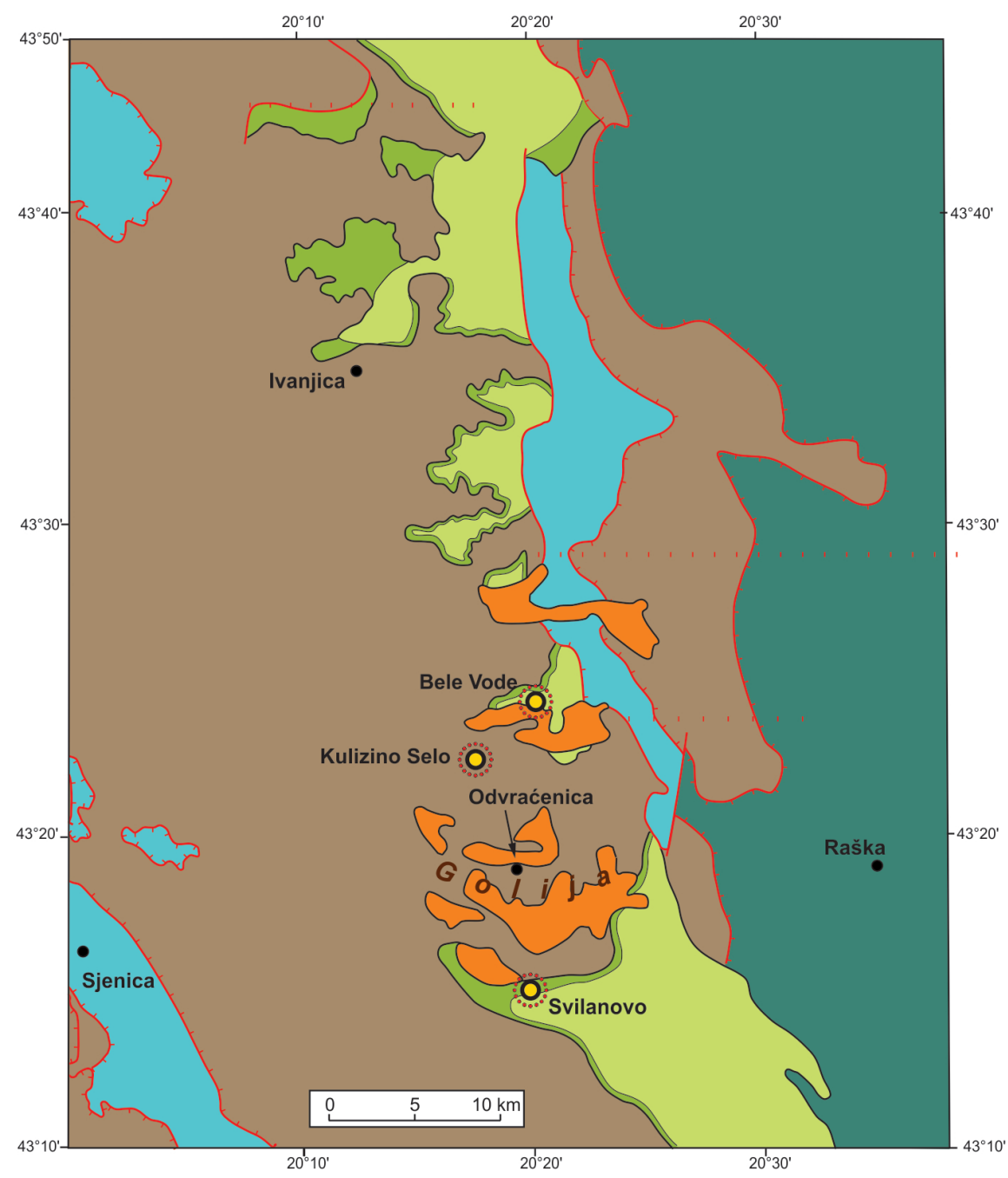

Figure 1. A simplified and modified geological map of the wider surroundings of the investigated area, based on the Geological Map of SFRY 1:500000 (SAVEZNI GEOLOŠKI ZAVOD, 1970).

the Maastrichtian when flysch sedimentation began (MOJSILOVIĆ et al., 1980; FILIPOVIĆ et al., 1978).

The wider investigated area belongs to the Cretaceous cover of Palaeozoic rocks on the eastern rim of the Drina-Ivanjica Unit, i.e. to a belt of Cretaceous sediments, known as „Novi Pazar Cretaceous, (RAMPNOUX, 1970) that can be traced from Kosovo towards the north and northwest to the area of Dragačevo. The complete Cretaceous stratigraphic sequence can be traced only in the western part of this belt.

In this area, the Cretaceous sedimentary succession begins with a $30 \mathrm{~m}$ thick basal conglomerate and conglomeratic limestone succession, which is overlain by a shallow-water limestone with Santonian-Campanian fauna represented by hippuritids, radiolitids, globotruncanids, gastropods and echinoids which is about $50 \mathrm{~m}$ thick. Rudist limestones are generally considered as products of typical reefal sedimentation (e.g. MILOVANOVIĆ, 1960; ROSS, 1992; KOCH et al., 2002). However, there are other opinions (e.g. GILI et al., 1995; SANDERS, 1998) suggesting that Cretaceous rudists were unable to build bioherms similar to Holocene coral reefs, but were gregarious sediment-dwelling aclonal suspension feeders. Cretaceous sedimentation ends with a thick sequence of preflysch and flysch sediments of Campanian and Maastrichtian age (RAMPNOUX, 1964, PETROVIĆ \& JANKIČEVIĆ, 1988), i.e. the so-called Kosovska Mitrovica flysch (DIMITRIJEVIĆ \& DIMITRIJEVIĆ, 1987; DIMITRIJEVIĆ, 1997).
In the area between Čačak and Novi Pazar, outcrops of the Upper Cretaceous rudist limestone occur in the form of a narrow strip along the rim of the overlying flysch deposits. There are also several small lenslike bodies of rudist limestone on the northern slopes of Golija Mountain. With an abundance of exceptionally large and well-preserved fossils, three localities at which the Upper Cretaceous limestone are exposed, Svilanovo, Kulizino Selo and Bele Vode, should be considered as potentially important for Serbian geoheritage (Fig. 1).

Svilanovo village is located on the southern slopes of Mt. Golija, about seven kilometres from the mountain peak Odvraćenica (N $43^{\circ} 14 ' 40^{\prime \prime} \mathrm{E} 20^{\circ} 19^{\prime} 54^{\prime \prime}$ ). Direct access to the locality is along a good asphalt road that branches from the Novi Pazar-Golija road. Lying over low-grade metamorphosed schists of Carboniferous age, Upper Cretaceous rudist limestone makes a conspicuous, more than $500 \mathrm{~m}$ long scarp along a relatively steep slope (Fig. 2).

The massive biomicritic limestone was deposited under shallow-water conditions. A heterogeneous fossil association comprises foraminifers, detritus of bivalves, gastropods, echinoids, corals, etc. (Fig. 3). The dominant macrofossils are rudist bivalves (Fig. 4) from the genera Radiolites, Lapeirouseia, Pironea, Hippurites, etc. (ĆIRIĆ, 1996).

In the nearby vicinity, another profile of Upper Cretaceous rudist limestone is exposed in the village of Bele Vode, on the northern slopes of Golija mountain, along the Ivanjica-Golija road 


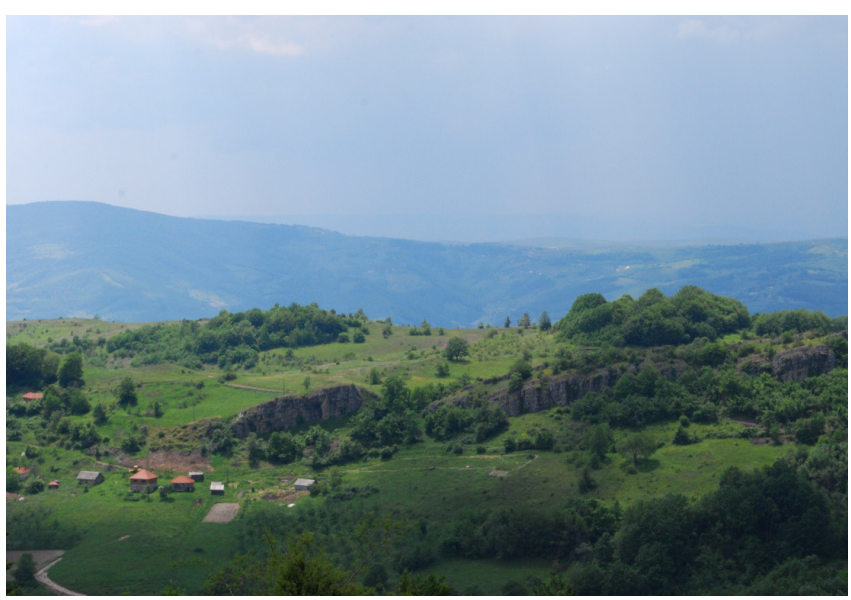

Figure 2. Scarp composed of Upper Cretaceous rudist limestone, Svilanovo village.

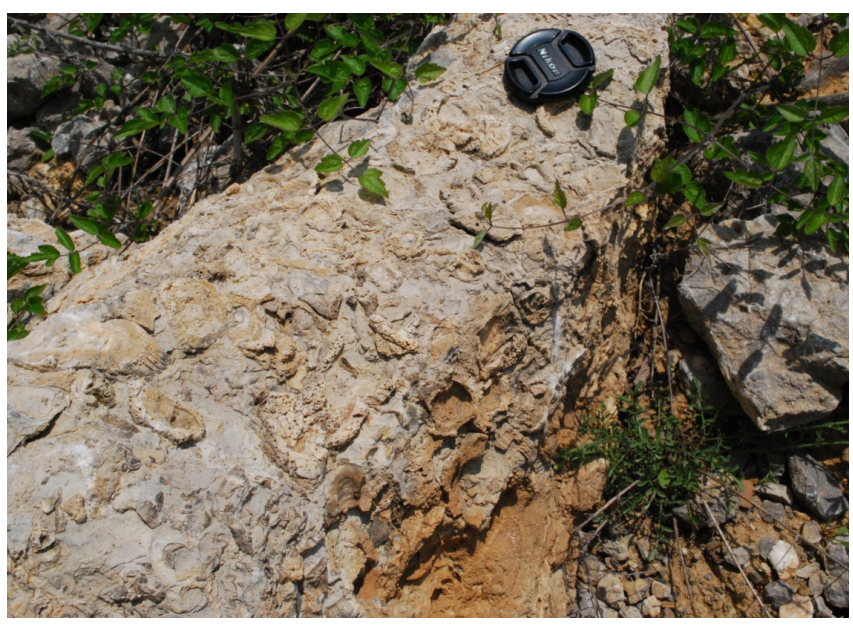

Figure 3. Abundant fossils in Upper Cretaceous limestone, locality Svilanovo.

(N 4324'09" E 20¹7'50"). At this locality, Upper Cretaceous sediments transgressively overlie Carboniferous schists. The Upper Cretaceous sequence starts with clastic sediments which are overlain by light gray biomicritic limestone with abundant rudists, corals and echinoids. The sedimentation regime was occasionally interrupted by the inflow of clayey-silty material, which resulted in the occurrence of several metres of bedded marly limestone. The succession ends with a massive limestone that contains rudists from the genera Lapeirouseia, Hippurites, $R a$ diolites, Pironea, etc. (Fig. 5).

The third locality is situated in the village of Kulizino Selo, south of Bele Vode (N 4322'55' E $20^{\circ} 17^{\prime} 32$ '). At this locality, Cretaceous rudist limestone lies above a relatively thin sequence composed of clastic sediments. A horizon of yellowish clayey limestone with densely packed small rudists, other bivalves and gastropods occurs within the massive limestone with large rudists (Fig. 6). Rudists at this locality mostly belong to the following genera: Lapeirouseia, Vaccinites, Hippurites, Radiolites and Pironea. The most important rudist specimen belongs to the species Lapeirouseia crateriformis. With a diameter of the upper valve of more than $60 \mathrm{~cm}$, it is the largest rudist ever found in the Dinarides (ĆIRIĆ, 1996).

These geosites are important for understanding the evolution of the wider region of Golija Mountain, making this area of great scientific value, particularly considering palaeontology, stratigraphy, palaeoecology and palaeogeography.

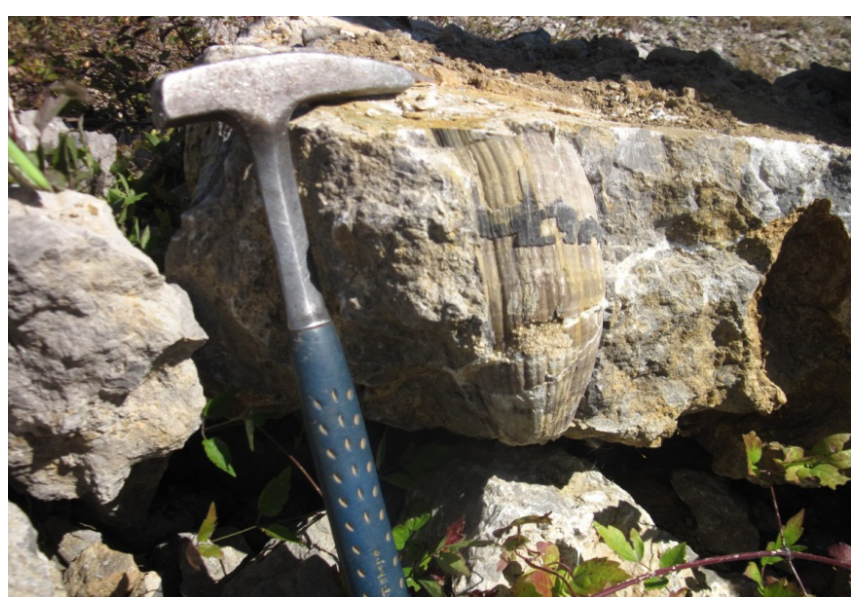

Figure 4. A rudist bivalve in growth position.

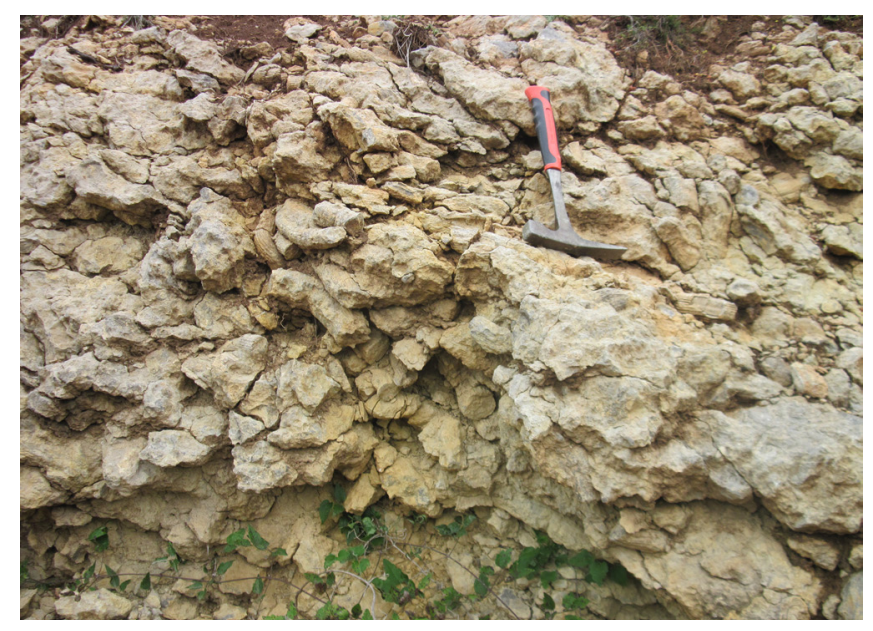

Figure 5. Limestone with rudist bivalves at the locality of Bele Vode.

Eastern and central Mediterranean Rudist species Vaccinites atheniensis Ktenas (younger synonym of $V$. chaperi; STEUBER, 1999), occurring at all these localities (MILOVANOVIĆ, 1975),

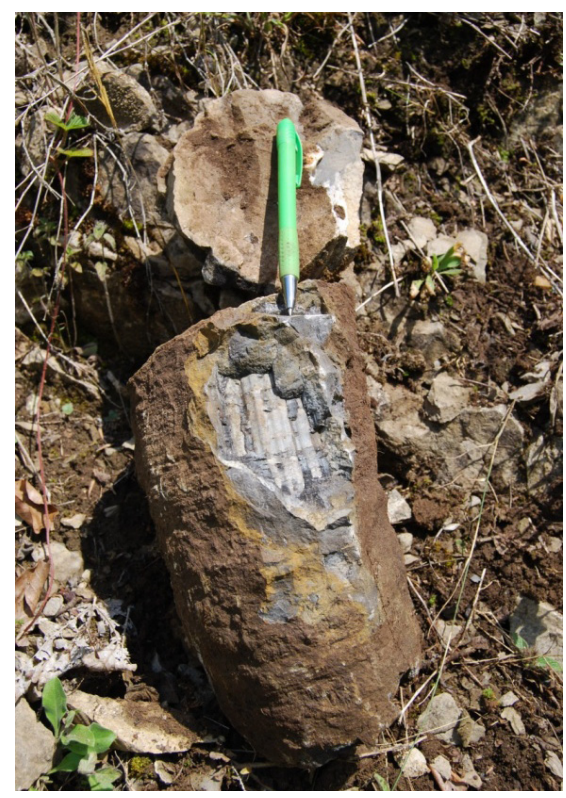

Figure 6. A large rudist specimen, Kulizino Selo locality. 
can be used for correlation with sedimentary rocks from distant regions. According to MILOVANOVIĆ (1934), in the terrains of Serbia (vicinity of Kosovska Mitrovica, Novi Pazar, Raška, Golija) this species belongs to the same association as in the Gossau Cretaceous sediments of the Eastern Alps, thus it should have the same stratigraphic position as in the eastern Alps, i.e. Late Santonian - Early Campanian. Recent chemostratigraphic ages reported from the surrounding regions (SWINBURNE at al., 1992) indicate the Campanian age of similar rudist-bearing limestones. Besides, these sediments show strong similarities to the limestone of the Pučišća Fm. in the eastern part of Brač (vicinity of Povlja) in Croatia, which are assigned an early Campanian age (STEUBER et el., 2005). Therefore, considering the absence of micropalaeontological data from our localities and the recently revised ages of similar rudist associations in the wider region, the general age of the rudist limestone on Golija Mt. is probably Campanian (?early Campanian).

\section{METHODS}

There are numerous papers on the evaluation of geosites worldwide (e.g. HENRIQUES et al., 2011; TOMIĆ, 2011; VUJIČIĆ et al., 2011; MOUFTI et al., 2013; PETROVIĆ et al., 2013; VASILJEVIĆ et al., 2014; GNEZDILOVA et al., 2015; BOŠKOV et al., 2015; BEGAN \& VIŠNIĆ, 2015). Different methods have been proposed for geoheritage assessment (e.g. PRALONG, 2005; PEREIRA et al., 2007; REYNARD et al., 2007; VUJIČIĆ et al., 2011; FASSOULAS et al., 2012; TOMIĆ \& BOŽIĆ, 2014; MARAN STEVANOVIĆ, 2015) based on quantification of different characteristics of geosites.

In this paper, evaluation of the chosen localities is based on the preliminary geosite assessment model (GAM), created by VUJIČIĆ et al. (2011). This method involves the quantification of two groups of indicators. The first group (Main values) comprises scientific/educational (VSE), scenic/aesthetical (VSA) and protection (VPr) values. These values are crucial for geoheritage assessment. However, the other group of indicators (Additional values), which includes functional (VFn) and touristic values (VTr), is important for considering the geotouristic potential of a site. All indicators are assigned values grading from 0 to 1 .

After evaluating each element in both groups of indicators, the total value was calculated for each group. The results obtained are presented in a discrimination diagram, where the Main and Additional values for each site are plotted against each other along the $\mathrm{X}$ and $\mathrm{Y}$ axes, respectively. The matrix is divided into nine fields and the position of each geosite within one of these fields shows its importance as an object of geoheritage and suggests plans of action for protection and sustainable management of the geosite.

\section{RESULTS AND DISCUSSION}

With the aim of evaluating the geosites on Golija Mt., three localities have been studied as potentially interesting sites of geoheritage significance. Main and Additional values for each subindicator are given in Tables 1 and 2, respectively. According to MOUFTI et al. (2013), short explanations for the assigned values are given in Tables 1 and 2. The total scores of the Main indicators were plotted against the values of the Additional indicators (Fig. 7).

The Svilanovo locality has a high value of Main (8.75) and medium value of Additional (7.75) indicators. The overall grade puts the Svilanovo locality (GS1) in the $\mathrm{Z}_{32}$ cell (Fig. 7). The value of the Main indicators (Table 1) is relatively high, considering the

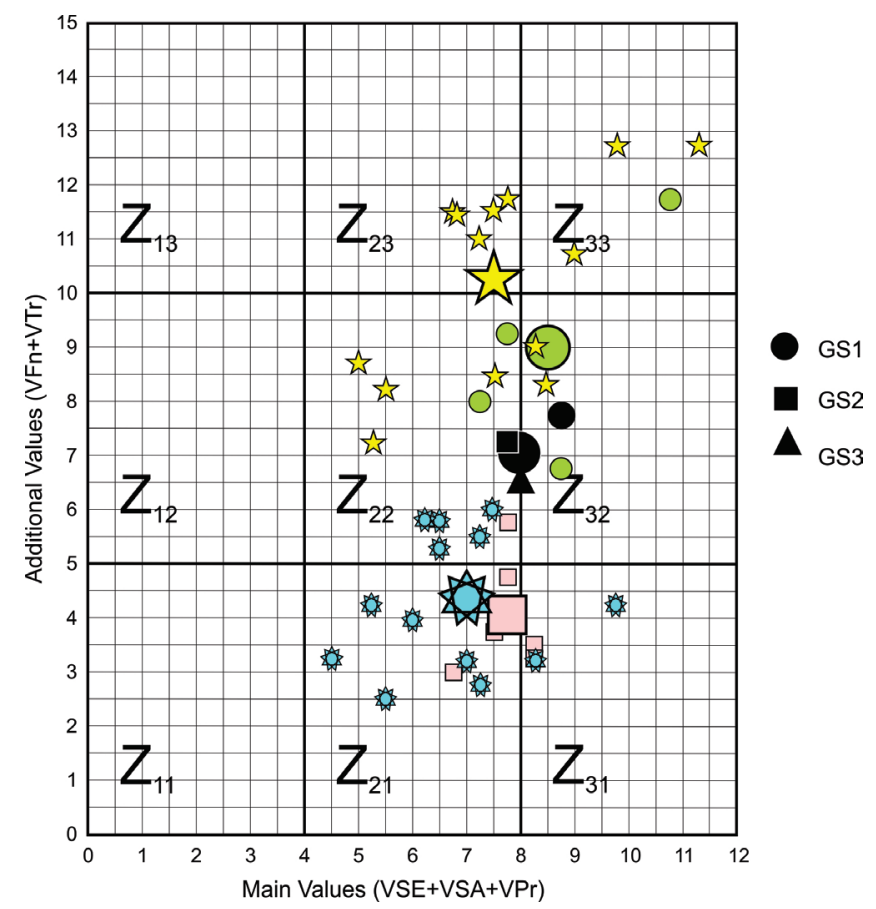

Figure 7. Location of the assessed geosites (GS 1 - Svilanovo, GS 2 - Bele Vode, GS 3 - Kulizino Selo) in GAM matrix, together with other previously evaluated geosites in the region. Legend: -geosites on Fruška Gora Mt. (VUJIČIĆ et al., 2011); $\hat{\imath}$ - geosites on Papuk Mt. (PETROVIĆ et al., 2013); $\square$ - geosites in Bela Crkva Municipality (BOŠKOV et al., 2015); $\bigcirc$ - geosites in SE Serbia (BEGAN \& VIŠNIĆ, 2015). Mean values for each group of geosites is presented by large symbols.

fact that there is no formal protection whatsoever. Additional values (Table 2) are at a moderate-to-high level due to a poorly developed touristic sector (no promotion, interpretative panels or tour guide service).

The Bele Vode locality (GS2) is in the $\mathrm{Z}_{22}$ field (Fig. 7). The Main indicator value (7.75) for this locality is somewhat lower due to the fact that there was short-lived limestone exploitation at this locality (Table 1). Additional indicators value (7.25) is also slightly lower than in the previous locality (Table 2).

The third locality, Kulizino Selo (GS3) falls on the boundary between $Z_{22}$ and $Z_{32}$ (Fig. 7). The overall Main indicators value (8.00) is quite similar to that of the previous two localities (Table 1 ), but the final grade is lower due to the much lower values of the Additional indicators (6.50; Table 2).

Finally, we compared our results with other geological and geomorphological sites evaluated using the same method, i.e. the localities on Fruška Gora Mt. (VUJIČIĆ et al., 2011; PETROVIĆ et al., 2013) and Papuk Mt. (PETROVIĆ et al., 2013), as well as in Bela Crkva municipality (BOŠKOV et al., 2015) and other evaluated geomorphological geosites in SE Serbia (BEGAN \& VIŠNIĆ, 2015) (Table 3).

It is evident from Fig. 7 that, according to the mean Main indicator values, the analyzed geosites on Golija Mt., as all other geosites in the region that were previously evaluated by GAM method, fall in the fields $Z_{2 y}$ and $Z_{3 y}(y=1,2,3)$. This indicates their scientific significance and potential for geotourism and geoconservation.

The obtained data show that the mean value for the group of indicators of Main Values for the studied geosites on Golija Mt. (8.16) is slightly higher than for most of the other evaluated sites in the region. Analysis of different subindicators of Main values shows that although VSE and VPr are balanced and relatively 
Table 1. Main values (according to the GAM method proposed by VUJIČIĆ et al., 2011) of geosites of Golija Mt.

\begin{tabular}{|c|c|c|c|}
\hline Geosites/Geotopes & Svilanovo & Bele Vode & Kulizino Selo \\
\hline \multicolumn{4}{|c|}{ I Scientific/Educational values (VSE) } \\
\hline \multicolumn{4}{|c|}{ 1. Rarity } \\
\hline \multicolumn{4}{|l|}{ Common $=0$} \\
\hline \multicolumn{4}{|l|}{ Regional $=0.25$} \\
\hline National $=0.5$ & $\begin{array}{l}\mathbf{0 . 5} \text { - Upper Cretaceous limestone with } \\
\text { rudist fauna, rare in the Serbian part of the } \\
\text { Dinarides, probably not so unique globally }\end{array}$ & $\begin{array}{l}\mathbf{0 . 5} \text { - Upper Cretaceous limestone with } \\
\text { rudist fauna, rare in the Serbian part of the } \\
\text { Dinarides, probably not so unique globally }\end{array}$ & $\begin{array}{l}\mathbf{0 . 5} \text { - Upper Cretaceous limestone with } \\
\text { rudist fauna, rare in the Serbian part of the } \\
\text { Dinarides, probably not so unique globally }\end{array}$ \\
\hline
\end{tabular}

International $=0.75$

Dinarides, probably not so unique globally Dinarides, probably not so unique globally Dinarides, probably not so unique globally

The only occurrence $=1$

2. Representativeness

None $=0$

Low $=0.25$

Moderate $=0.5$

$\mathbf{0 . 5}$ - fairly representative for Upper Cretaceous rudist-bearing carbonate platform environment $\mathbf{0 . 5}$ - fairly representative for Upper Cretaceous rudist-bearing carbonate platform environment
High $=0.75$

$\mathbf{0 . 7 5}$ - representative for Upper Cretaceous

rudist-bearing carbonate platform

environment in western Serbia, similar

outcrops are known elsewhere

Utmost $=1$

3. Knowledge on geo-scientific issues

None $=0$

Local publications $=0.25$

Regional publications $=0.5$

National publications $=0.75$

$\mathbf{0 . 7 5}$ - locality known from national geological literature $\mathbf{0 . 7 5}$ - locality known from national geological literature $\mathbf{0 . 7 5}$ - locality known from national geological literature

International publications $=1$

4. Level of interpretation

\section{None $=0$}

Moderate level of processes but hard

to explain to non experts $=0.25$

Good example of processes but

hard to explain to non experts $=0.5$

$\mathbf{0 . 5}$ - perfect example of Cretaceous

reef-like bioconstructions, but basic geological knowledge necessary to understand the palaeoenvironment $\mathbf{0 . 2 5}$ - relatively good example of Upper Cretaceous reef-like bioconstructions; basic

geological knowledge necessary to understand the palaeoenvironment $\mathbf{0 . 2 5}$ - relatively good example of Upper geological knowledge necessary to understand the palaeoenvironment

Moderate level of processes but easy

to explain to common visitor $=0.75$

Good example of processes and easy

to explain to common visitor=1

II Scenic/Aesthetic values (VSA)

1.Viewpoints (each must present a particular angle of view and be situated less than $1 \mathrm{~km}$ from the site)

None $=0$

One $=0.25$

2 to $3=0.5$

$\mathbf{0 . 5}$ - transgressive boundary between the Late Palaeozoic metamorphics and the Upper Cretaceous limestone; a Miocene volcanic neck with columnar jointing in the vicinity $\mathbf{0 . 5}$ - Upper Cretaceous rudist limestone; Late Palaeozoic metamorphics nearby $\mathbf{0 . 5}$ - Upper Cretaceous rudist limestone; Late Palaeozoic metamorphics nearby

4 to $6=0.75$

More than $6=1$

2. Surface (each considered in quantitative relation to other)

Small $=0$

$\mathrm{SM}=0.25$

Medium $=0.5$

$\mathrm{ML}=0.75$

Large $=1$

3. Surrounding landscape and nature

Minimum $=0$

Low $=0.25$

Medium-0.5

High $=0.75$

$\mathbf{0 . 7 5}$ - situated in a beautiful valley. The locality is surrounded by sparsely wooded

Utmost $=1$

1-the area is several 100s of metres in size 1-the area is several 100s of metres in size

1-the area is several 100 s of metres in size

4. Environmental fitting of sites

Unfitting $=0$

$\mathrm{UN}=0.25$

Neutral $=0.5$

$\mathrm{NF}=0.75$

Fitting $=1$
1 - from the top of Golija Mt., adorable view 1 - situated on a slope with beautiful view of the Pešter Plateau (Sjeničko Polje and of the top of the Golija Mt and the Kopaonik Novopazarsko Polje). The locality is Mt. The locality is surrounded by sparsely surrounded by sparsely wooded wooded topography with meadows and topography with meadows and pastures pastures $\mathbf{0 . 7 5}$ - limestone exploitation started at this locality, but it was shortlived 


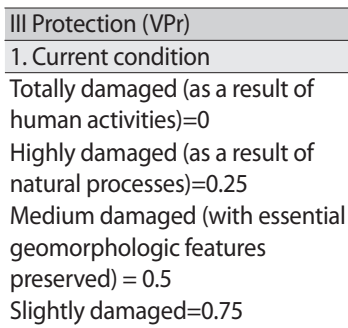

(2)

$\mathbf{0 . 7 5}$ - effects of previous exploitation still visible on the site

1 - completely preserved site

0-no formal protection $\quad$ 0-no formal protection

Local $=0.25$

Reginal $=0.5$

National $=0.75$

International=1

3. Vulnerability

Irreversible (with possibility of tota

loss) $=0$

High (could be easily dama-

ged $)=0.25$

Medium (could be damaged by

natural processes or human

activities) $=0.5$

Low (could be damaged only by

human activities) $=0.75$

$\mathbf{0 . 7 5}$ - potential collectors of rudists could damage the outcrop faces $\mathbf{0 . 7 5}$ - potential collectors of rudists could damage the outcrop faces $\mathbf{0 . 7 5}$ - potential collectors of rudists could damage the outcrop faces

4. Suitable number of visitors

Zero $=0$

0 to $10=0.25$

10 to $20=0.5$

20 to $50=0.75$

More than $50=1$

1 - the open places can hold more than $50 \quad \mathbf{1}$ - the open places can hold more than 50

1 - the open places can hold more than 50 visitors at any one time visitors at any one time

Total (VSE+VSA+VPr) 8.75 7.75

visitors at any one time 8.00

Table 2. Additional values (according to the GAM method proposed by VUJIČIĆ et al., 2011) of geosites of Golija Mt.

\begin{tabular}{|c|c|c|c|}
\hline Geosites/Geotopes & Svilanovo & Bele Vode & Kulizino Selo \\
\hline \multicolumn{4}{|c|}{ I Functional values (VFn) } \\
\hline \multicolumn{4}{|c|}{ 1. Accessibility } \\
\hline \multicolumn{4}{|c|}{ Inaccessible $=0$} \\
\hline \multicolumn{2}{|c|}{$\begin{array}{l}\text { Medium (by bicycle and other means of } \\
\text { man-powered transport) }=0.5\end{array}$} & & \\
\hline High (by car) $=0.75$ & & & $\begin{array}{l}\mathbf{0 . 7 5} \text { - the site is along the road, easily } \\
\text { accessible by car }\end{array}$ \\
\hline Utmost (by bus)=1 & $\begin{array}{l}1 \text { - the site is along the road, easily } \\
\text { accessible by bus }\end{array}$ & $\begin{array}{l}1 \text { - the site is along the road, easily } \\
\text { accessible by bus }\end{array}$ & \\
\hline \multicolumn{4}{|c|}{ 2. Additional natural values } \\
\hline \multicolumn{4}{|c|}{ None $=0$} \\
\hline One $=0.25$ & $\begin{array}{l}0.25 \text { - a site of pyramidal fir (Abies alba } \\
\text { var. pyramidalis) }\end{array}$ & & \\
\hline 2 to $3=0.5$ & & $\begin{array}{l}\mathbf{0 . 5} \text { - a site of pyramidal fir (Abies alba } \\
\text { var. pyramidalis); a lot of springs in the } \\
\text { vicinity }\end{array}$ & $\begin{array}{l}0.5 \text { - a site of pyramidal fir (Abies alba } \\
\text { var. pyramidalis); a lot of springs in the } \\
\text { vicinity }\end{array}$ \\
\hline \multicolumn{4}{|l|}{4 to $6=0.75$} \\
\hline \multicolumn{4}{|c|}{ More than $6=1$} \\
\hline \multicolumn{4}{|c|}{ 3. Additional anthropogenic values } \\
\hline \multicolumn{4}{|c|}{ None $=0$} \\
\hline \multicolumn{4}{|l|}{ One $=0.25$} \\
\hline \multicolumn{4}{|l|}{2 to $3=0.5$} \\
\hline 4 to $6=0.75$ & & & $\begin{array}{l}\mathbf{0 . 7 5} \text { - plantations of raspberries; } \\
\text { Orthodox Medieval monasteries of } \\
\text { Studenica, Gradac, Đurđevi Stupovi and } \\
\text { Sopoćani; Saint Apostles Peter and Paul } \\
\text { Church, the oldest in the Balkans. }\end{array}$ \\
\hline More than $6=1$ & $\begin{array}{l}1 \text { - seasonal mountain settlements } \\
\text { („,katuni, }) \text {; plantations of raspberries; } \\
\text { Orthodox Medieval monasteries of } \\
\text { Studenica, Gradac, Đurđevi Stupovi and } \\
\text { Sopoćani; Saint Apostles Peter and Paul } \\
\text { Church, the oldest in the Balkans. }\end{array}$ & $\begin{array}{l}1 \text { - several sculpture fountains; } \\
\text { plantations of raspberries; Orthodox } \\
\text { Medieval monasteries of Studenica, } \\
\text { Gradac, Đurđevi Stupovi and Sopoćani; } \\
\text { Saint Apostles Peter and Paul Church, the } \\
\text { oldest in the Balkans. }\end{array}$ & \\
\hline
\end{tabular}


4. Vicinity of emissive centres

More than $100 \mathrm{~km}=0$

100 to $50 \mathrm{~km}=0.25$

50 to $25 \mathrm{~km}=0.5$

0.5 - 35km from Ivanjica

25 to $5 \mathrm{~km}=0.75$

0.75 - 20km from Novi Pazar

Less than $5 \mathrm{~km}=1$

5 . Vicinity of important road network

None $=0$

Local $=0.25$

$\mathbf{0 . 2 5}$ - the asphalt road Novi Pazar-Golija $\quad \mathbf{0 . 2 5}$ - the local asphalt road

0.25 the local asphalt road

Regional $=0.5$

National $=0.75$

International=1

6. Additional functional values

None $=0$

Low $=0.25$

Medium $=0.5$

High $=0.75$

Utmost $=1$

1 - along the asphalt road to Novi

1 - along the asphalt road to the village of $\mathbf{1}$ - along the asphalt road to the village of Pazar-Golija and Sjenica-Golija Bele Vode Kulizino Selo

II Touristic values (VTr)

1. Promotion

None $=0$

0

Local $=0.25$

Regional $=0.5$

National $=0.75$

International $=1$

2. Annual number of organized visits

None $=0$

Less than 12 per year $=0.25$

12 to 24 per year $=0.5$

24 to 48 per year $=0.75$

More than 48 per year $=1$

3. Vicinity of visitors centre

More than $50 \mathrm{~km}=0$

50 to $20 \mathrm{~km}=0.25$

20 to $5 \mathrm{~km}=0.5$

5 to $1 \mathrm{~km}=0.75$

0.75 - In the Golija Nature Park

$\mathbf{0 . 2 5}$ - geologists, geology students

$\mathbf{0 . 2 5}$ - geologists, geology students

$\mathbf{0 . 2 5}$ - geologists, geology students

Less than $1 \mathrm{~km}=1$

4. Interpretative panels (characteristics of text and graphics, material quality, size, fitting to surroundings, etc.)

None $=0$

0

0

0.5 - rural tourism

$\mathbf{0 . 5}$ - rural tourism

Low quality $=0.25$

Medium quality $=0.5$

High quality $=0.75$

Utmost quality $=1$

5 . Annual number of visitors

None $=0$

Low (less than 5000) $=0.25$

0.25

0.25

0.25

Medium (5001 to 10.000) $=0.5$

High (10.001 to 100.000) $=0.75$

Utmost (more than 100.000) $=1$

6. Tourism infrastructure (pedestrian pathways, resting places, garbage cans, toilets, wellsprings etc.)

None $=0$

Low $=0.25$

Medium $=0.5$

$\mathbf{0 . 5}$ - pedestrian paths in the vicinity, wellsprings

$\mathbf{0 . 5}$ - pedestrian paths in the vicinity, wellsprings $\mathbf{0 . 5}$ - pedestrian paths in the vicinity, wellsprings

High $=0.75$

Utmost $=1$

7. Tour guide service (expertise level, knowledge of foreign language(s), interpretative skills, etc)

None $=0$

0

0

Low $=0.25$

Medium $=0.5$

High $=0.75$

Utmost $=1$

8. Hostelry service

More than $50 \mathrm{~km}=0$

$25-50 \mathrm{~km}=0.25$

$10-25 \mathrm{~km}=0.5$

0.5 - On Golija Mt

$\mathbf{0 . 5}$ - On Golija Mt

5-10 km=0.75

Less than $5 \mathrm{~km}=1$

9. Restaurant service

More than $25 \mathrm{~km}=0$

$10-25 \mathrm{~km}=0.25$

$10-5 \mathrm{~km}=0.5$

$5-1 \mathrm{~km}=0.75$

Less than $1 \mathrm{~km}=1$

Total (VFn + VTr)

0.75 - On Golija Mt

7.75

1 - On Golija Mt

0 
Table 3. Mean Main and Additional values for different geosites in Croatia and Serbia, according to the GAM method proposed by VUJIČIĆ et al., 2011.

\begin{tabular}{|c|c|c|c|c|c|}
\hline Geosites & $\begin{array}{c}\text { Papuk Mt. } \\
\text { (according to } \\
\text { PETROVIĆ et al., 2013) }\end{array}$ & $\begin{array}{l}\text { Fruška Gora Mt. } \\
\text { (according to } \\
\text { VUJIČIĆ et al., 2011) }\end{array}$ & $\begin{array}{l}\text { Bela Crkva municipality } \\
\text { (according to } \\
\text { BOŠKOV et al., 2015) }\end{array}$ & $\begin{array}{c}\text { SE Serbia } \\
\text { (according to } \\
\text { BEGAN \& VIŠNIĆ, 2015) }\end{array}$ & $\begin{array}{c}\text { Golija Mt. } \\
\text { (this publication) }\end{array}$ \\
\hline Mean Main Values & 7.57 & 7.02 & 7.70 & 8.55 & 8.15 \\
\hline VSE & 2.43 & 2.46 & 2.00 & 3.30 & 2.16 \\
\hline VSA & 2.71 & 2.43 & 2.83 & 2.56 & 3.33 \\
\hline VPr & 2.43 & 2.13 & 2.87 & 2.69 & 2.66 \\
\hline Mean Additional Values & 10.25 & 4.29 & 4.00 & 8.90 & 7.16 \\
\hline VFn & 3.61 & 2.94 & 2.37 & 4.50 & 4.08 \\
\hline Vtr & 6.64 & 1.35 & 1.63 & 4.40 & 3.08 \\
\hline
\end{tabular}

high, the differences in Main values mostly depend on VSA. The highest VSA for the studied geosites on Golija Mt. (3.33) are due to the large surface areas of the outcrops, the beautiful landscape and their untouched nature. Most of the subindicators representing Protection (VPr) are very high for geosites on Golija Mt., but they are significantly lowered due to the lack of any kind of formal protection. Although VSE for sites on Golija Mt. are quite satisfactory (2.16), low values of Level of interpretation show that these geosites might be interesting in the first instance for people with a geoscience background.

The calculated mean Additional values of different groups of geosites greatly differ (from $Z_{x 1}$ to $Z_{x 3}, x=1,2,3$ ), depending on the overall development of an area, the number of potential visitors, touristic infrastructure, management and planning, vicinity of emissive centres, etc. Mean values for the group of indicators of Additional Values for the studied localities are much lower than for geosites on Papuk Mt. and in SE Serbia, but much higher than for those on Fruška Gora Mt. and in Bela Crkva municipality. Despite rather similar Functional values (VFn) to geosites is SE Serbia and generally higher than those on Papuk Mt., geosites on Golija Mt. have much lower Touristic values (VTr). The main reason for this is insufficient development of tourism in this area. Such low VTr obtained for the studied geosites are compensated for by relatively high VFn, which results in generally high Additional Values.

\section{CONCLUSIONS}

The obtained results show that the Main indicators values of the analyzed geosites are high and that these localities are important from a scientific and educational point of view, which leads to the conclusion that Golija Mountain has sufficient levels of natural resources for geotourism development.

The Additional indicators values are at a medium level in all three geosites. This is not surprising, considering the fact that this is a problem for many potential sites of geoheritage significance in Serbia, because of the lack of organized visits, tour guide service, interpretative panels, etc. This implies that there is an urgent need for more rapid, though sustainable, development of the tourism infrastructure.

In order to maintain the original characteristics of these geosites, it would be necessary to protect them from negative influences that might result in degradation or complete devastation. The final aim is geoconservation of the geosites in their original, undisturbed condition, in order to preserve it for future generations. The most effective way of protection of objects of geoheritage significance is to raise the awareness of their scientific, educational, aesthetic and touristic importance, as well as to forbid their commercial exploitation. This paper shows that all the studied localities fully deserve such treatment.

\section{ACKNOWLEDGMENT}

The work was supported by the Ministry of Education, Science and Technological Development of the Republic of Serbia (Project No. 176015). We also thank the editor and two anonymous reviewers for their constructive comments, which helped us to improve the manuscript.

\section{REFERENCES}

BEGAN, M. \& VIŠNIĆ, T. (2015): Comparative Analysis of Gorges and Canyons in Southeastern Serbia as Potential Geotouristic Destinations by Using Gam Model.Asian Journal of Multidisciplinary Studies, 3/11, 4-11.

BOŠKOV, J., KOTRIA, S., JOVANOVIĆ, M., TOMIĆ, N., LUKIĆ, T. \& RVOVIĆ, I. (2015): Application of the Preliminary Geosite Assessment Model (GAM): The Case of the Bela Crkva Municipality (Vojvodina, North Serbia).- Geographica Pannonica, 19/3, 146-152.

CSONTOS, L., GERZINA, N., HRVATOVIĆ, H., SCHMID, S. \& TOMLJENOVIĆ, B. (2003): Structure of the Dinarides: a working model.- Ann. Univ. Sci. Budapest., Sect. Geol., 35, 143-144.

ĆIRIĆ, B. (1996): Geologija Srbije [Geology of Serbia - in Serbian].- Geokarta, Beograd, 273 p.

DIMITRIJEVIĆ, M.D. (1997): Geology of Yugoslavia.- Geol. Inst. GEMINI Spec. Publ., Belgrade, $187 \mathrm{p}$.

DIMITRIJEVIĆ, M.D. (2001): Dinarides and the Vardar Zone: a short review of the geology.-Acta Vulcanol., 13, 1-8.

DIMITRIJEVIĆ, M.N. \& DIMITRIJEVIĆ, M.D. (1973): Olistostrome mélange in the Yugoslavian Dinarides and late Mesozoic plate tectonics.- J. Geol., 81/3, 328-340.

DIMITRIJEVIĆ, M.N. \& DIMITRIJEVIĆ, M.D. (1987): The Titova Mitrovica Flysch.In: DIMITRIJEVIĆ, M.N. \& DIMITRIJEVIĆ, M.D. (eds.): The trubiditic basins of Serbia. Serbian Academy of Sciences and Arts Department of Natural \& Mathematical Sciences, 61, 25-64.

ĐUROVIĆ, P. \& MIJOVIĆ, D. (2006): Geonasleđe Srbije - reprezent njenog ukupnog geodiverziteta [Geoheritage of Serbia-Representative of its Total Geodiversity-in Serbian].- Zbornik Radova Geografskog Fakulteta u Beogradu, 54, 5-18.

FASSOULAS, C., MOURIKI, D., DIMITRIOU-NIKOLAKIS, P. \& ILIOPOULOS, G. (2012): Quantitative Assessment of Geotopes as an Effective Tool for Geoheritage Management.- Geoheritage, 4, 177-193.

FILIPOVIĆ, I., MARKOVIĆ, B., PAVLOVIĆ, Z., RODIN, V. \& MARKOVIĆ, O. (1978): Osnovna geološka karta SFRJ 1: 100000. Tumač za list Gornji Milanovac L34-137 [Basic Geologic Map of SFRY 1: 100.000. Explanatory booklet for the Sheet Gornji Milanovac - in Serbian].- Savezni geološki zavod, Beograd.

GILI, E., MASSE, J-P. \& SKELTON. P.W. (1995): Rudists as gregarious sediment dwellers, not reef-builders, on Cretaceous carbonate platforms.- Palaeogeography, Palaeoclimatology, Palaeoecology, 118, 245-267.

GNEZDILOVA, V., RUBAN, D., BRUNO, D., PERROTTA, P., CROWLEY, B., OHEIM, K. \& ZAYATS, P. (2015): Geoheritage sites with palaeogeographical value: some geotourism perspectives with examples from Mountainous Adygeja (Russia).- Geološki anali Balkanskoga poluostrva, 76, 93-104.

HENRIQUES, M., BRILHA, J., MOTA, T. \& PENA DOS REIS, R. (2011): Geoconservation as an Emerging Geoscience.- Geoheritage, 3/2, 117-128.

HRVATOVIĆ, H. \& PAMIĆ., J. (2005): Principal thrust-nappe structures of the Dinarides. - Acta Geologica Hungarica, 48/2, 133-151.

JOVANOVIĆ, V., CAREVIĆ, I., VUŠKOVIĆ, D. \& KHALILABAD, T.M. (2012): Review and protection possibilities of some trans-border (East Serbia - West Bulgaria) stratigraphic/palaeontological geosites.- Bulletin of the Serbian Geographical Society, 92/1, 171-184.

KARAMATA, S. (2006): The geological development of the Balkan Peninsula related to the approach, collision and compression of Gondwana and Eurasian units.- In: ROBERTSON, A.H.F. \& MOUNTRAKIS, D. (eds.): Tectonic development of the Eastern Mediterranean Region.- Geol. Soc. London, Spec. Publ.,260, 155-178. 
KARAMATA, S. \& MIJOVIĆ, D. (2005): Inventar objekata geonasleđa Srbije [Inventory of the geological heritage sites of Serbia - in Serbian, English abstract].In: MIJOVIĆ, D. (ed.): II Intern. Symp. on geoheritage of Serbia. Bull. Inst. of Nature Conserv., Sp. Issue, 20, 1-36.

KOCH, R., MOUSSAVIAN, E., OGORELEC, B., SKABERNE, D. \& BUCUR, I. (2002): Development of a Lithocodium (syn. Bacinella irregularis)-reef-mound- A patch reef within Middle Aptian lagoonal limestone sequence near Nova Gorica (Sabotin Mountain, W-Slovenia).- Geologija, 45/1, 71-90.

MARAN, A. (2008): Geoconservation in the Balkan region - Practices and legal instruments.- Bulletin of the Natural History Museum, Belgrade, 1, 41-63.

MARAN, A. (2010): Valuing the geological heritage of Serbia.- Bulletin of the Natural History Museum, Belgrade, 3, 47-66.

MARAN STEVANOVIĆ, A. (2015): Methodological guidelines for geoheritage site assessment: a proposal for Serbia.- Geološki anali Balkanskoga poluostrva, 76, $105-113$.

MIJOVIĆ, D., RUNDIĆ, LJ. \& MILOVANOVIĆ, D. (2005): Zaštita geonasleđa u Srbiji i pravci razvoja [Protection of geoheritage of Serbia and future development - in Serbian, English abstract].- In: MIJOVIĆ, D. (ed.): II Intern. Symp. on geoheritage of Serbia. Bull. Inst. of Nature Conserv., Sp. Issue, 20, 17-21.

MILOVANOVIĆ, B. (1934): Rudisna fauna Jugoslavije, Istočna Srbija, zapadna Srbija, Stara Raška [Rudist fauna of Yugoslavia, Eastern Serbia, Western Serbia, Stara Raška - in Serbian].- Geološki anali Balkanskoga Poluostrva, 12/1, 186-213.

MILOVANOVIĆ, B. (1960): Stratigraphie du Sénonien dans les Dinarides Yougoslaves d'après les Rudistes.- Bull. Soc. Géol. France, 7/2, 366-375.

MILOVANOVIĆ, B. (1975): Jugozapadna Srbija.[Southwestern Serbia].- In: PETKOVIC, K. (ed.): Geologija Srbije, II-2, Stratigrafija, mezozoik. Zavod za regionalnu geologiju i paleontologiju Rudarsko-geološkog fakulteta, Univerzitet u Beogradu, 327-331.

MOJSILOVIĆ, S., BAKLAJIĆ, D. \& ĐOKOVIĆ, I., (1980): Osnovna geološka karta SFRJ 1: 100000. Tumač za list Sjenica [Basic Geologic Map of SFRY 1: 100.000. Explanatory booklet for the Sheet Sjenica - in Serbian].- Savezni geološki zavod, Beograd, $46 \mathrm{p}$.

MOUFTI, M.R., NÉMETH, K., EL-MASRY, N. \& QADDAH, A. (2013): Geoheritage values of one of the largest maar craters in the Arabian Peninsula: the Al Wahbah Crater and other volcanoes (Harrat Kishb, Saudi Arabia).- Central European Journal of Geosciences, 5/2, 254-271.

PAMIĆ, J., GUŠIĆ, I. \& JELASKA, V. (1998): Geodynamic evolution of the Central Dinarides.- Tectonophysics, 297, 251-268.

PAMIĆ, J. \& HRVATOVIĆ, H. (2000): Dinaride Ophiolite Zone (DOZ).- In: PAMIĆ, J. \& TOMLJENOVIĆ, B. (eds.): Pancardi 2000 Fieldtrip Guidebook.- Vijesti, 37/2, 60-68.

PEREIRA, P., PEREIRA, D. \& CAETANO ALVES, M.I. (2007): Geomorphosite assessment in Montesinho Natural Park (Portugal).- Geographica Helvetica, 62, 159-168.

PETROVIĆ, M. \& JANKIČEVIĆ, J. (1988): Stratigraphic column of the Upper Cretaceous near Novi Pazar.- Geološki anali Balkanskoga poluostrva, 52, 107-113.

PETROVIĆ, M.D., VASILJEVIĆ, DJ.A., VUJIČIĆ, M.D., HOSE, T.A., MARKOVIĆ, S. B. \& LUKIĆ, T. (2013): Global Geopark and Candidate-Comparative analysis of Papuk Mountain Geopark (Croatia) and Fruška Gora Mountain (Serbia) by using GAM Model.- Carpathian Journal of Earth and Environmental Sciences, 8/1, $105-116$.

PRALONG, J.P. (2005): A method for assessing the tourist potential and use of geomorphological sites. - Géomorphologie: Relief, processus, environnement, 3, 189-196.

RABRENOVIĆ, D., BELIJ, S., MOJSIĆ, I. \& MLADENOVIĆ, M. (2014): Main Values of the Đerdap area, Potential Geopark.-In: CVETKOVIĆ, V. (ed.): Proceedings of the XVI Serbian Geological Congress, Donji Milanovac, May 22-25, 866-871.
RAMPNOUX, J.-P. (1964): Sur le Cretace du versant ouest du Kopaonik région de Novi Pazar (Stara Raška) Yugoslavia.- Bull. Soc. Géol. France, 7, VI/2, 219-224.

RAMPNOUX, J.-P. (1970): Regards sur les Dinarides internes yougoslaves (Serbie Monténégro oriental): stratigraphie, évolution paléogéographique, magmatisme.-Bull. Soc. Géol. France, 12/6, 948-966.

REYNARD, E., FONTANA, G., KOZLIK, L. \& SCAPOZZA, C. (2007): A method for assessing ,scientific” and ,additional values” of geomorphosites.- Geographica Helvetica, 62/3, 148-158.

ROBERTSON, A.H.F. \& KARAMATA, S. (1994): The role of subduction-accretion processes in the tectonic evolution of the Mesozoic Tethys in Serbia.- Tectonophysics, 234, 73-94.

ROSS, D.J. (1992): Sedimentology and depositional profile of a mid-Cretaceous shelf edge rudist reef complex, Nahal Ha'mearot, NW Israel.- Sedimentary Geology, $79,161-172$.

RUNDIĆ, LJ. \& KNEŽEVIĆ, S. (2005): Stratigrafsko-paleontološki objekti kao integralni deo geonasledja Srbije [Stratigraphical and palaeontological objects as an integral part of Serbian geoheritage - in Serbian, English abstract].- In: MIJOVIĆ, D. (ed.): II Intern. Symp. on geoheritage of Serbia., Bull. Inst. of Nature Conserv., Sp. Issue, 20, 109-114.

SANDERS, D. (1998): Upper Cretaceous „Rudist Formations,,.- Geol. Palëont. Mitt. Innsbruck., 23, 37-59.

SAVEZNI GEOLOŠKI ZAVOD (Federal Geological Survey) (1970): Geološka karta SFR Jugoslavije, 1:500000 [Geologic Map of SFRY, 1:500.000], Beograd.

SCHMID, M.S., BERNOULLI, D., FÜGENSCHUH, B., MATENCO, L., SCHEFER, S., SCHUSTER, R., TISCHLER, M. \& USTASZEWSKI, K. (2008): The AlpineCarpathian-Dinaridic orogenic system: correlation and evolution of tectonic units.Swiss J. Geosci., 101/1, 139-183.

STEUBER, T. (1999): Cretaceous rudists of Boeotia, central Greece.- Spec. Papers in Paleontology, 61, $229 \mathrm{p}$.

STEUBER, T., KORBAR, T., JELASKA, V. \& GUŠIĆ, I. (2005): Strontium-isotope stratigraphy of Upper Cretaceous platform carbonates of the island of Brač (Adriatic Sea, Croatia): Implications for global correlation of platform evolution and biostratigraphy.- Cretaceous Research, 26/5, 741-756.

STOJANOVIĆ, V. \& MIJOVIĆ, D. (2008): Evaluation of geodiversity of the Western Bačka Danube region in the planning documents and opportunities for improvement.-Collection of papers Geographical Institute „Jovan Cvijić,,, 58, $5-16$.

SWINBURNE, N.H.M., BILOTTE, M. \& PAMOUKTCHIEV, A. (1992): The stratigraphy of the Campanian-Maastrichtian rudist beds of Bulgaria and reassessment of the range of the genus Pironea.- Cretaceous Res., 13, 191-205.

TOMIĆ, N. (2011): The potential of Lazar Canyon (Serbia) as a geotourism destination: inventory and evaluation.- Geographica Pannonica, 15/3, 103-112.

TOMIĆ, N. \& BOŽIĆ, S. (2014): A modified Geosite Assessment Model (M-GAM) and its Application on the Lazar Canyon area (Serbia).- Int. J. Environ. Res., 8/4, 1041-1052.

VASILJEVIĆ, DJ.A., MARKOVIĆ, S.B., HOSE, T.A., DING, Z., GUO, Z., LIU, X., SMALLEY, I., LUKIĆ, T. \& VUJIČIĆ, M.D. (2014): Loess-palaeosoil sequences in China and Europe: Common values and geoconservation issues.- Catena, 117, 108-118.

VUJIČIĆ, M.D., VASILJEVIĆ, DJ.A., MARKOVIĆ, S.B., HOSE, T.A., LUKIĆ, T. \& HADŽIĆ, O. (2011): Preliminary Geosite Assessment Model (GAM) and its Application on Fruška Gora Mountain, Potential Geotourism Destination of Serbia.Acta geographica Slovenica, 51/2, 361-377. 